\title{
Bożena Alejziak
}

https://orcid.org/0000-0002-3821-8887

Akademia Wychowania Fizycznego w Krakowie

Wydział Turystyki i Rekreacji

Instytut Turystyki

bozena.alejziak@awf.krakow.pl

\section{KSZTAŁCENIE AKADEMICKIE A POZIOM KOMPETENCJI SPOŁECZNYCH STUDENTÓW KIERUNKU TURYSTYKA I REKREACJA}

\begin{abstract}
Abstrakt: Kompetencje społeczne to jeden z najważniejszych aspektów funkcjonowania jednostki w otaczającym świecie. Są one na tyle ważne, iż stały się - obok wiedzy i umiejętności - jednym z efektów kształcenia akademickiego. Poziom tych kompetencji uzależniony jest od uwarunkowań wewnętrznych jednostki, ale także od czynników środowiskowych. Celem niniejszego artykułu jest przedstawienie wyników badań dotyczących osiągniętego poziomu kompetencji społecznych studentów w trakcie edukacji akademickiej na kierunku turystyka i rekreacja. Aby zdiagnozować założony cel, wykorzystano ilościowe i jakościowe metody badań. $\mathrm{Na}$ ich podstawie ustalono, iż poziom kompetencji społecznych studentów biorących udział w badaniu jest przeciętny, pomimo że nauczyciele akademiccy deklarują realizację efektów kształcenia w tym zakresie.
\end{abstract}

Słowa kluczowe: kompetencje społeczne, kształcenie akademickie, studenci turystyki i rekreacji.

\section{WSTĘP}

Kompetencje społeczne są niezbędnym elementem warunkującym efektywność funkcjonowania jednostki w społeczeństwie (Argyle, 1998; Goleman, 1997). Należy jednak podkreślić, iż zdefiniowanie kompetencji społecznych jest dość trudne. Fakt ten budzi wiele kontrowersji wśród psychologów zajmujących się różnymi dziedzinami, którzy nie są zgodni co do definicji struktury tego konstruktu. Analizując literaturę przedmiotu, można zauważyć, iż termin ten często używany jest zamiennie z pojęciem umiejętności społecznych, relacyjnych, interakcyjnych czy komunikacyjnych (Jakubowska, 1996).

Według Argyle'a (1999) kompetencja społeczna to posiadanie niezbędnych umiejętności do tego, by wywrzeć pożądany wpływ na innych ludzi w sytuacjach społecznych. Autor wskazuje także na dwie kategorie umiejętności społecznych pozwalających uzyskać zamierzone efekty w różnych sytuacjach. Są to umiejętności społeczne powszechne, potrzebne każdemu człowiekowi, oraz profesjonalne, niezbędne w wielu zawodach.

Jakubowska (1996) przyjmuje, że kompetencja społeczna jest warunkowana przez sumę takich elementów relacji, jak psychiczne dyspozycje oraz umiejętności odbioru i nadawania komunikatów zgodnych zarówno z wzorcem sytuacji, jak i obranym celem osobistym jednostki. Jest to komunikacyjne ujęcie tego konstruktu.

Podejście relacyjne prezentują natomiast Spitzberg i Cupach (2002), którzy proponują statyczne i dynamiczne rozumienie pojęcia kompetencji społecznych. Pierwsze z nich zakłada, że wspomniane umiejętności są zachowaniami zmierzającymi do nawiązania, podtrzymania i zakończenia relacji międzyludzkich, drugie natomiast opisuje je jako zachowania celowe, dostosowane do sytuacji, wyuczone i kontrolowane przez jednostkę.

Z kolei Greenspan (1981) utożsamia kompetencje społeczne z dyspozycją warunkującą sukces w relacjach interpersonalnych, co jest zależne od pewnych zdolności intelektualnych oraz cech charakteru. Matczak (2001) natomiast poszerza tę definicję o interakcję czynników osobowościowo-intelektualnych ze środowiskiem, w którym funkcjonuje człowiek. W tym wypadku ważną rolę odgrywa tzw. trening społeczny, czyli podejmowane przez jednostkę działania w toku jej życia. Jest to więc model interakcyjny. 


\section{KOMPETENCJE SPOŁECZNE JAKO ELEMENT KSZTAŁCENIA AKADEMICKIEGO}

Kompetencje społeczne mają na tyle kluczowe znaczenie we współczesnym świecie, iż aktualnie stanowią jeden $z$ trzech głównych elementów efektów uczenia się na poziomie akademickim zgodnie z Zaleceniem Parlamentu Europejskiego i Rady z dnia 23 kwietnia 2008 roku w sprawie ustanowienia Europejskich Ram Kwalifikacji (2008; zob. też: Bereźnicki, 2011; Nowakowska, Pietkiewicz, 2016) $)^{1}$.

Efekty uczenia się definiowane są przez określenie tego, co uczący się wie, rozumie i potrafi wykonać po zakończeniu procesu uczenia się, i można je podzielić na trzy kategorie, takie jak: wiedza, umiejętności i kompetencje (Europejskie Ramy Kwalifikacji..., 2009). W Polsce opisano je w Polskiej Ramie Kwalifikacji (Chłoń-Domińczak, Sławiński, Kraśniewski, 2015; Rydzewska-Włodarczyk, 2017; Sławiński, 2017).

Efekty uczenia się są środkiem, dzięki któremu można skupić uwagę na rzeczywistych osiagnięciach studentów, co stanowi bardziej realistyczny i rzeczywisty wykładnik wartości kształcenia niż mierniki samego nauczania (Maher, 2004). Efekty kształcenia są zintegrowane z programem studiów i jak podkreśla Kraśniewski (2009), ze względu na ich duże znaczenie w procesie edukacji, powinny być mierzalne oraz mierzone przez instytucje prowadzącą kształcenie. W związku z tym kwalifikacje studenta są potwierdzane odpowiednim dyplomem.

Biorąc pod uwagę te rozważania, celem badań prezentowanych $w$ niniejszym artykule było ustalenie, jaki poziom kompetencji społecznych, których charakterystyka została zamieszczona w dokumencie Opis kierunkowych efektów kształcenia (Opis kierunkowych efektów kształcenia dla studiów I stopnia..., 2020; Opis kierunkowych efektów kształcenia dla studiów II stopnia..., 2020), prezentują studenci kierunku turystyka i rekreacja w Akademii Wychowania Fizycznego w Krakowie.

Z takiego opisu dla studiów I stopnia wynika, że studenci $w$ ramach realizowanego programu kształcenia w formie wykładów, ćwiczeń, obozów i praktyk zawodowych powinni osiągnąć w obszarze kompetencji społecznych m.in. umiejętność:

- uzupełniania i doskonalenia kwalifikacji poprzez samodzielne zdobywanie wiedzy i zdolności w zakresie wybranej specjalności zawodowej;

- realistycznego oceniania swoich możliwości i kompetencji, zwłaszcza w zakresie rzetelnego i bezpiecznego wykonywania zadań związanych z turystyką i rekreacja;

- kierowania się zasadami etyki zawodowej;

- wykazania dbałości o bezpieczeństwo osób uczestniczących $\mathrm{w}$ zajęciach rekreacyjnych i imprezach turystycznych;
- pracowania w zespole;

- sprawnego komunikowania się z ludźmi, także $\mathrm{w}$ warunkach stresu, zapewnienie im bezpieczeństwa oraz przekazywania informacji związanych z programem zajęć, a także prawidłowego interpretowania oczekiwań uczestników prowadzonych zajęć;

- zainteresowania przekazywaną wiedzą krajoznawczą i metodyczną osób o różnym poziomie wykształcenia, biorących udział $w$ imprezach turystycznych i zajęciach rekreacyjnych;

- wyrażania swojej opinii w sprawach zawodowych z zakresu turystyki i rekreacji (Opis kierunkowych efektów kształcenia dla studiów I stopnia..., 2020).

Natomiast na studiach II stopnia o profilu ogólnoakademickim powinny to być m.in. umiejętności:

- samodzielnego uzupełniania posiadanej wiedzy, realistycznego oceniania swoich kompetencji, bycia świadomym ich ograniczeń, również tych wynikających z potrzeby ochrony interesów innych osób;

- dostrzegania i formułowania problemów etycznych związanych z własną praca;

- sprawowania przywództwa nad kierowanym zespotem, a także nad uczestnikami imprez turystycznych i zajęć rekreacyjnych;

- oceniania warunków realizacji podejmowanych zadań i takich, które zostały danej osobie powierzone, oraz określania priorytetów w działaniach służących ich realizacji;

- brania odpowiedzialności za kierowanie pracą zespołu realizującego zadanie;

- kierowania zadaniami w sposób zapewniający bezpieczeństwo współpracowników i uczestników imprez turystycznych i zajęć rekreacyjnych;

- formułowania samodzielnych opinii dotyczących wybranych aspektów działalności zawodowej w zakresie turystyki i rekreacji, opartych na rzeczowej argumentacji;

- bycia przedsiębiorczym (Opis kierunkowych efektów kształcenia dla studiów II stopnia..., 2020).

Takie zdefiniowanie efektów kształcenia akademickiego w zakresie kompetencji społecznych jednoznacznie wskazuje, jak szerokie i nieujednolicone, niekiedy nawet intuicyjne jest rozumienie powyższej kategorii $\mathrm{w}$ szkolnictwie wyższym $\mathrm{w}$ ramach programów kształcenia.

Porównując opis kompetencji społecznych realizowanych w ramach programu kształcenia na kierunku turystyka i rekreacja w AWF w Krakowie z ich definicjami proponowanymi przez Argyle'a (1999), Jakubowską (1996) czy Greenspana (1981), można zauważyć znaczne rozbieżności w rozumieniu owych charakterystyk, co z pewnością wymagałoby jakiegoś ujednolicenia i jednoznacznego zdefiniowania tego fenomenu. W Polskiej Ramie Kwalifikacji (Chłoń-Domińczak, Sławiński, Kraśniewski, Chmielecka, 2017) kompetencje te odnoszą się raczej do szerokiego wachlarza zachowań o charakterze 
prospołecznym, czy nawet etycznym. Z kolei na kierunku turystyka i rekreacja w AWF w Krakowie kompetencje mają wymiar bardzo praktyczny i są ukierunkowane głównie na funkcjonowanie absolwenta w branży związanej z realizowanym kierunkiem studiów (Opis kierunkowych efektów kształcenia dla studiów I stopnia..., 2020; Opis kierunkowych efektów kształcenia dla studiów II stopnia..., 2020), wiążącej się - co warto podkreślić - z bardzo wieloma różnego rodzaju sytuacjami, w których wymagane jest posiadanie umiejętności interpersonalnych i relacyjnych.

Podczas prowadzenia badań najważniejszym wyzwaniem było jednak zdefiniowanie tego, jak należy rozumieć kompetencje społeczne kształtowane w grupie studentów, czy zakłada się ich celowość (Argyle, 1998), czyli skuteczność społeczna, czy ujęcie relacyjne (Spitzberg, Cupach, 2002), tj. umiejętność tworzenia zdrowych więzi społecznych. Z pewnością takie doprecyzowanie kompetencji społecznych na poziomie efektów kształcenia pozwoliłoby na lepsze projektowanie środków i metod dydaktycznych ukierunkowanych na ich osiąganie.

W związku z tak szerokim i rozmytym sposobem ujmowania kompetencji społecznych, analiza tego zjawiska w kontekście kształcenia akademickiego implikuje ujęcie koncepcji kompetencji społecznych najbardziej uniwersalnej, obejmującej najszerszą gamę sytuacji społecznych. Na te potrzeby najlepiej odpowiada rozumienie kompetencji społecznych - zgodnie z poglądami Greenspana (1981) - jako zmiennej indywidualnej o charakterze osobowościowym, która determinuje sukces interpersonalny, opierając się na interakcji czynników temperamentalnych, społecznych i intelektualnych.

Dodatkowej wartości eksplanacyjnej dostarcza rozwinięcie modelu opracowanego przez Matczak (2001), która proponuje podejście interakcyjne, rozszerzając to ujęcie o interakcję ze środowiskiem. W swojej koncepcji autorka definiuje kompetencje społeczne jako złożone umiejętności warunkujące efektywność regulacji emocjonalnej i radzenia sobie w różnego rodzaju sytuacjach społecznych. Zaprezentowana koncepcja, zgodnie z którą kompetencje społeczne nabywane są $\mathrm{w}$ trakcie treningu społecznego i opierają się na indywidualnych predyspozycjach, stanowi podstawę analiz do niniejszego artykułu. Zgodnie z tym modelem szeroko pojęte oddziaływanie akademickie jest jednym $\mathrm{z}$ elementów treningu społecznego, w tym przypadku $\mathrm{w}$ formie usystematyzowanej i w dużej mierze celowej. Warto zaznaczyć, że o jego intensywności decydują cechy indywidualne jednostki (osobowościowo-temperamentalne), a o efektywności - poziom rozwoju intelektualnego. Czynniki te, co warto zaznaczyć, wchodzą ze sobą w interakcje, a jednostka podlega jednocześnie wychowaniu i socjalizacji, jak też przejawia aktywność w kształtowaniu własnej osobowości i tożsamości.

\section{KSZTAtCENIE AKADEMICKIE JAKO FORMA TRENINGU SPOŁECZNEGO}

Kluczowe dla zrozumienia zróżnicowania poziomu kompetencji społecznych w grupie studentów kierunku turystyka i rekreacja jest zrozumienie, że kształcenie akademickie odgrywa rolę treningu społecznego. Stanowi ono w interakcyjnej koncepcji kształtowania kompetencji społecznych element treningu, który wraz z cechami temperamentalno-osobowościowymi studentów będzie wyznaczał efektywność tych działań. Tak więc analiza zjawiska zależności między kompetencjami społecznymi a oddziaływaniami akademickimi na studiach na kierunku turystyka i rekreacja, czy też jakimkolwiek innym, wymaga spojrzenia na tę kwestię - przynajmniej w pewnym zakresie - z perspektywy zarówno sytuacyjnej, jak i osobowej przy uwzględnieniu dynamiki rozwojowej.

Zgodnie z założeniem kompetencje społeczne można kształtować podczas tzw. treningu, co na poziomie akademickim ma zawiązek z realizacją programu kształcenia. Istotne znaczenie mają tutaj interakcja z nauczycielami akademickimi oraz metody nauczania stosowane przez nich podczas prowadzenia wykładów, ćwiczeń, laboratoriów, obozów, ćwiczeń terenowych oraz interakcja z potencjalnymi lub aktualnymi pracodawcami podczas realizacji praktyk zawodowych, a także uczestnictwo w międzynarodowej wymianie Erasmus. Jak uważa bowiem Nowak-Dziemianowicz (2012), edukacja jest tym rodzajem treningu społecznego, który musi odpowiadać lokalnym, narodowym, a także globalnym potrzebom.

W tym kontekście zaskakuje fakt, że przy tak istotnej i wciąż rosnącej roli kompetencji społecznych ocena realizacji efektów kształcenia w ich zakresie jest mierzona zasadniczo bez jakichkolwiek kryteriów zewnętrznych, na poziomie czysto subiektywnym i arbitralnym. Dysponujemy ograniczoną informacją zwrotną $\mathrm{w}$ postaci samooceny studenta oraz oceny wykładowcy. Wynika to zapewne z faktu, iż budowanie programów studiów na podstawie Europejskich i Polskich Ram Kwalifikacji daje uczelniom wyższym daleko idącą autonomię w zakresie określania kierunków, planów studiów i efektów kształcenia (Chmielecka, 2010; Nowak-Dziemianowicz, 2012). Oznacza to, że obecnie nie istnieje obiektywny system ich ewaluacji zarówno na poziomie akademickim, jak i później, na etapie badań losów absolwentów. Zaskakuje mała liczba publikacji dotyczących tego ważnego zagadnienia. Przy tak dużej istotności problemu literatura przedmiotu jest bardzo uboga (Pacana, Woźny, Sobczyńska, 2016; Piróg, 2016; Rocki, 2018; Smółka, 2008), a w przypadku kierunku turystyka i rekreacja - wymagająca aktualizacji (Różycki, 1998).

Jednym z kluczowych czynników decydujących o planowaniu skuteczności treningu jest znajomość wyjściowego poziomu i natężenia zróżnicowania nabywanych 
kompetencji oraz trafna i rzetelna informacja zwrotna o jego wynikach. O ile mamy pewien zakres wiedzy dotyczącej kompetencji społecznych pracowników sektora turystycznego (Alejziak, 2014; Burzyński, 2019), o tyle niewiadomą jest sam wyjściowy poziom tych kompetencji u studentów przyjmowanych na uczelnię. Efektem kształcenia akademickiego powinno być przygotowanie studentów do wymogów rynku pracy, czyli do potrzeb i oczekiwań pracodawców, przy czym warto zaznaczyć, że biorąc pod uwagę kształcenie na szczeblu szkoły średniej, wiadomo, jaką wiedzę i umiejętności posiada student, jednak można jedynie zakładać, na jakim poziomie są jego kompetencje społeczne.

\section{CEL BADAŃ I METODA}

Biorąc pod uwagę zaprezentowane tu rozważania, celem przeprowadzonych badań była diagnoza poziomu kompetencji społecznych studentów kierunku turystyka i rekreacja oraz interakcja tych kompetencji z doświadczeniami o charakterze edukacyjnym na poziomie akademickim. Założono bowiem, że wraz z długością stażu akademickiego będzie wzrastał poziom kompetencji społecznych, a sprzyjać temu powinno w szczególny sposób odbywanie praktyk zawodowych oraz uczestnictwo w programie wymiany międzynarodowej Erasmus, realizowanym w środowisku zróżnicowanym kulturowo.

Główny problem sformułowano następująco: w jakim zakresie edukacja akademicka różnicuje poziom kompetencji społecznych studentów turystyki i rekreacji na studiach licencjackich i magisterskich? Aby dokładniej sprecyzować problem postawiono kilka szczegółowych pytań badawczych:

1. Jaki jest poziom kompetencji społecznych młodzieży studiującej na kierunku turystyka i rekreacja?

2. Czy doświadczenie kształcenia akademickiego różnicuje studentów turystyki i rekreacji w zakresie poziomu kompetencji społecznych?

3. Jaki wpływ na poziom kompetencji społecznych ma uczestnictwo w wymianie międzynarodowego kształcenia studentów w ramach programu Erasmus oraz innych tego typu?

4. Jaki związek z poziomem kompetencji społecznych mają praktyki zawodowe realizowane przez studentów turystyki i rekreacji?

W celu zdiagnozowania poziomu kompetencji społecznych zastosowano Kwestionariusz Kompetencji Społecznych (KKS) opracowany przez Matczak (2001), będący podstawowym narzędziem wykorzystywanym przy diagnozowaniu poziomu i zakresu kompetencji społecznych studentów w trzech obszarach, takich jak: - efektywność zachowań w sytuacjach ekspozycji społecznej (ES),
- efektywność zachowań w sytuacjach wymagających asertywności (A),

- efektywność zachowań w sytuacjach intymnych (I). KKS jest narzędziem psychologicznym² pozwalającym na zastosowanie wystandaryzowanej metody diagnozy wybranych kompetencji społecznych, mającym potwierdzoną trafność i rzetelność. Jest to kwestionariusz samoopisowy, którego pozycje są określeniami różnych czynności lub zadań, wyrażonymi w formie bezokolicznikowej. Spośród nich $2 / 3$ (60 pozycji) dotyczą różnych czynności społecznych, a 1/3 (30 pozycji) to pozycje niediagnostyczne, związane z czynnościami, które nie mają charakteru społecznego.

W badaniach zastosowano także autorski kwestionariusz „Samoocena Osiągnięć Zawodowych Studenta”, na podstawie którego zdiagnozowano m.in. takie elementy edukacji, jak: rodzaj ukończonej szkoły średniej, profil klasy, rok studiów, uzyskiwane oceny, praktyki (ich długość oraz otrzymana ocena), udział w międzynarodowej wymianie edukacyjnej w ramach programu Erasmus oraz innych, realizacja drugiego kierunku studiów. Kwestionariusz zawierał pytania:

- skategoryzowane;

- takie, w których zastosowano pięciopunktową skalę Likerta;

- otwarte, diagnozujące opinię młodzieży na temat własnego rozwoju zawodowego ${ }^{3}$.

Badając poziom kompetencji społecznych w grupie studentów turystyki i rekreacji, wyniki studiów poddano analizie statystycznej, która obejmowała przeprowadzenie podstawowych charakterystyk liczbowych i procentowych oraz analizę zależności i związków w obrębie badanych zmiennych. Analizę statystyczną przeprowadzono z wykorzystaniem programu statystycznego Statistica 10 firmy StatSoft Polska. Do zbadania różnic międzygrupowych użyto testu t-Studenta dla zmiennych niezależnych, testu U Manna-Whitneya (gdy liczebność była zbyt mała lub rozkład wyników odbiegał od rozkładu normalnego), jednoczynnikowej analizy wariancji ANOVA (w przypadku porównywania więcej niż dwóch grup) oraz dwuczynnikowej analizy wariancji MANOVA do zbadania interakcji grupa × płeć. Przy analizie korelacji posłużono się testami r-Pearsona oraz rho-Spearmana. Za ważne przyjęto prawdopodobieństwo testowe na poziomie $p<0,05$, a za wysoce istotne - na poziomie $p<0,01$ i $p<0,001$. Wstępna analiza wyników Kwestionariusza Kompetencji Społecznych polegała na obliczeniu wyników, jakie uzyskują badane osoby w poszczególnych skalach KKS: Skali Kontaktów Intymnych, Skali Ekspozycji Społecznej, Skali Asertywności, oraz obliczeniu ogólnego wyniku surowego (Total WS).

Dobór grupy badawczej był celowy, oparty na kryterium studiów na wybranym kierunku w trybie stacjonarnym. Tak więc badaniami objęci zostali studenci studiujący w trybie stacjonarnym na kierunku turysty- 
ka i rekreacja w Akademii Wychowania Fizycznego im. B. Czecha w Krakowie. Autorka artykułu przeprowadziła badania osobiście w 2019 r., w trakcie zajęć dydaktycznych, stosując tradycyjną, papierową wersję narzędzi badawczych. Celem badaczki było pozyskanie jak największej liczby respondentów. Na wspomnianym kierunku formalnie $\mathrm{w}$ danym roku studiowało 660 osób. Udział w badaniach był dobrowolny. Po przedstawieniu celu badań oraz jego uzasadnieniu, kwestionariusz „Samoocena Osiągnięć Zawodowych Studenta" wypełniło 511 osób, natomiast Kwestionariusz Kompetencji Społecznych - 442 osoby.

Podczas prowadzenia analiz otrzymanych wyników respondentów podzielono na trzy grupy różniące się pod względem kategorii doświadczeń edukacyjnych. Zabieg ten wpłynął na większą przejrzystość w prezentacji wyników. Ich analiza w pięciu grupach nie przyniosła jednak zamierzonego efektu, ponieważ różnice w otrzymanych wskaźnikach nie były istotne.

\section{PREZENTACJA WYNIKÓW BADAŃ}

\subsection{CHARAKTERYSTYKA GRUPY BADAWCZEJ}

Charakteryzując ogółem wszystkich respondentów, można zauważyć, iż na kierunku turystyka i rekreacja większość stanowią kobiety (73\%), a tylko co trzeciaczwarta osoba biorąca udział w badaniu to mężczyzna $(27 \%)$. Ta struktura jest podobna we wszystkich trzech grupach badanych (I rok studiów licencjackich: 69,6\% kobiet i 30,4\% mężczyzn; II-II rok studiów licencjackich - 77,0\% kobiet i 23\% mężczyzn; studia uzupełniające magisterskie - 71,2\% kobiet i 28,8\% mężczyzn) - rys. 1. Większość badanych osób ukończyła liceum ogólnokształcące $(74,21 \%)$, a co czwarty respondent - technikum (25,79\%). Podobną strukturę można

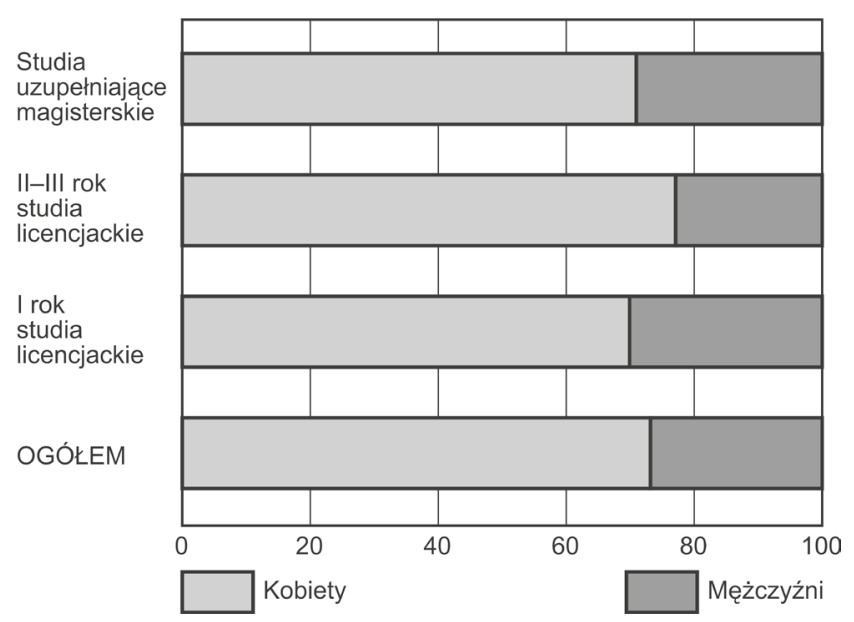

Rysunek 1. Płeć respondentów Źródło: opracowanie własne zauważyć na I roku studiów licencjackich (70,06\% to absolwenci liceum, a 29,94\% - technikum) oraz II i III (74,88\% i 25,12\%), a także na studiach uzupełniających magisterskich $(78,26 \%$ i $21,74 \%)$ - rys. 2 .

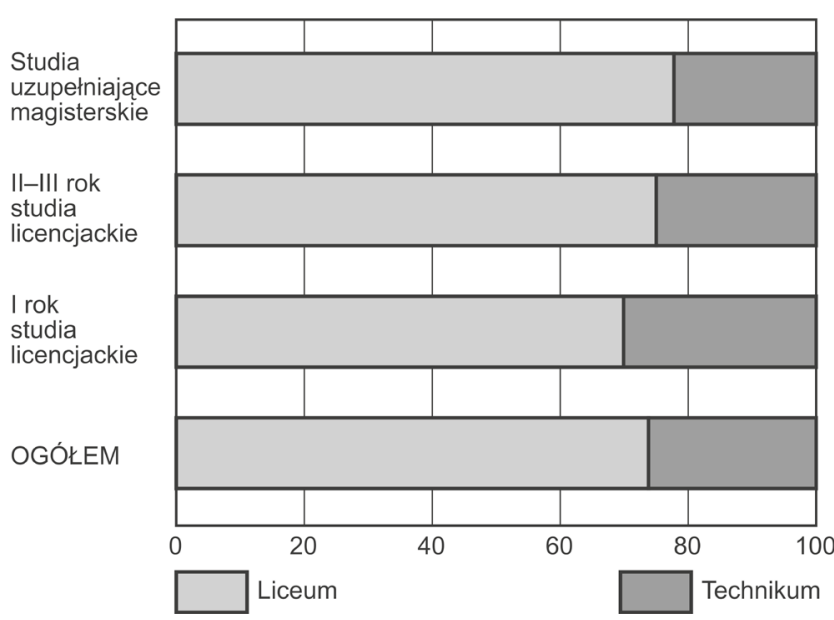

Rysunek 2. Rodzaj ukończonej szkoły Źródło: opracowanie własne

Analizując wyniki w nauce (rys. 3), na podstawie zebranych opinii respondentów ustalono, że większość z nich $(60,2 \%)$ otrzymuje oceny dobre, co czwarty $(26,2 \%)$ - oceny dostateczne, a więcej niż co dziesiąty $(13,6 \%)$ - oceny bardzo dobre. Podobna struktura ocen występuje we wszystkich trzech analizowanych grupach: na I roku studiów licencjackich $(62,7 \% ; 22,3 \% ; 15,1 \%)$, na II i III roku (58,9\%; 29,7\%; 11,4\%) oraz na studiach uzupełniających magisterskich $(59,0 \% ; 25,9 \% ; 15,1 \%)$. Uogólniając osiągnięcia badanych respondentów, można zauważyć, że na kierunku turystyka i rekreacja przeważają studenci, których wyniki w nauce można sklasyfikować na poziomie dobrym.

Warto także zauważyć, że więcej niż co dziesiąta badana osoba $(15,46 \%)$ podjęła naukę na drugim kierunku

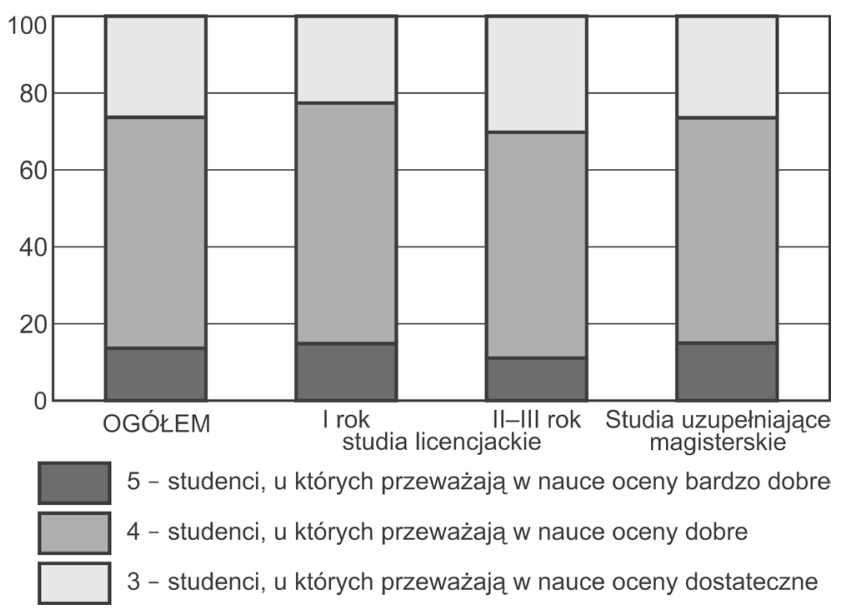

Rysunek 3. Oceny w nauce Źródło: opracowanie własne 


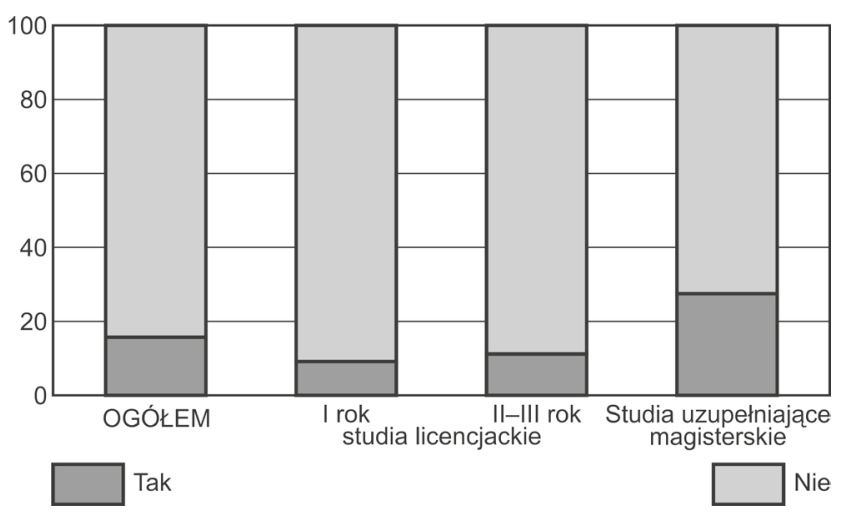

Rysunek 4. Drugi kierunek studiów Źródło: opracowanie własne

studiów (tym samym 84,54\% ankietowanych studiowało wyłącznie turystykę i rekreację na AWF). Najwięcej osób, które realizowały drugi kierunek (prawie co trzeci respondent), było na studiach magisterskich $(28,1 \%)$. Natomiast na studiach licencjackich dotyczy to mniej więcej co dziesiątej badanej osoby (na I roku - 9,5\%; na II i III - 11,8\%) - rys. 4 .

\subsection{POZIOM KOMPETENCJI SPOŁECZNYCH STUDENTÓW TURYSTYKII REKREACJI}

Podczas prowadzenia badań z użyciem dwuczynnikowej analizy wariancji postanowiono sprawdzić, czy istnieją różnice w poziomie kompetencji społecznych pomiędzy badanymi grupami, czyli studentami studiów licencjackich i magisterskich (przy jednoczesnym uwzględnieniu ich płci). Wyniki przeprowadzonych analiz wskazały jedynie istotne statystycznie różnice pomiędzy badanymi grupami w przypadku skali I (kompetencje warunkujące efektywność zachowań $\mathrm{w}$ sytuacjach intymnych) $-F(2,442)=3,129 ; \eta_{P}^{2}=0,014$; $p=0,045$. Opierając się na analizie post hoc, można stwierdzić, że poziom tych kompetencji studentów II i III roku studiów licencjackich jest istotnie statystycznie $(p<0,05)$ wyższy niż w przypadku studentów I i II roku studiów magisterskich; wartość cząstkowego eta kwadrat $\left(\eta^{2}{ }_{p}>0,014\right)$ świadczy o dużej sile efektu (Cohen, 1988; Cohen, Cohen, West, Aiken, 2003; Miles, Shevlin, 2001). W przypadku pozostałych zmiennych przeprowadzone analizy nie wskazały istotnych statystycznie różnic pomiędzy studentami poszczególnych lat studiów w odniesieniu do płci oraz interakcji: grupa $\times$ płeć $(p>0,05)$.

Wartości opisowe kwestionariusza KKS w badanych grupach przedstawiono $\mathrm{w}$ tabeli 1 . Wyniki testów statystycznych zaprezentowanych w kolejnej części artykułu odnoszą się do tych wartości (średnich oraz odchyleń), co pozwala wskazać różnice między grupami.

Dodatkowo wyniki badań przeliczono na wyniki unormowane (stenowe) dla populacji studentów. We wszystkich skalach średnie wartości stenowe plasowały się pomiędzy piątym a szóstym stenem, co świadczy o tym, że badani studenci turystyki i rekreacji prezentują przeciętny poziom kompetencji społecznych, nie różniąc się pod tym względem od studentów uczestniczących w badaniach Matczak i stanowiących grupę odniesienia. Co ciekawe, podobny wynik, czyli przeciętny, otrzymała Wierzejska (2016), która zbadała poziom kompetencji społecznych tym samym narzędziem wśród studentów kończących studia o profilu społecznym (dziennikarstwo i komunikacja społeczna, socjologia, psychologia i pedagogika) oraz ścisłym (chemia, biologia i biotechnologia, geografia) na Uniwersytecie Marii Curie-Skłodowskiej w Lublinie.

Tabela 1. Statystyki opisowe wyników kwestionariusza KKS w badanych grupach

\begin{tabular}{|c|c|c|c|c|c|c|c|c|c|c|c|c|c|}
\hline & \multicolumn{6}{|c|}{ Studia licencjackie } & \multirow{2}{*}{\multicolumn{3}{|c|}{$\begin{array}{c}\text { Studia magisterskie } \\
\text { I i II rok }\end{array}$}} & \multirow{2}{*}{\multicolumn{3}{|c|}{ Ogółem }} \\
\hline & & \multicolumn{3}{|c|}{ I rok } & \multicolumn{3}{|c|}{ II i II rok } & & & & & & \\
\hline $\begin{array}{c}\text { Skala } \\
\text { KKS }\end{array}$ & & $\begin{array}{c}\mathrm{K} \\
(\mathrm{N}=82)\end{array}$ & $\begin{array}{c}\mathrm{M} \\
(\mathrm{N}=33)\end{array}$ & $\begin{array}{c}\mathrm{O} \\
(\mathrm{N}=115)\end{array}$ & $\begin{array}{c}\mathrm{K} \\
(\mathrm{N}=149)\end{array}$ & $\begin{array}{c}\mathrm{M} \\
(\mathrm{N}=45)\end{array}$ & $\begin{array}{c}\mathrm{O} \\
(\mathrm{N}=194)\end{array}$ & $\begin{array}{c}\mathrm{K} \\
(\mathrm{N}=96)\end{array}$ & $\begin{array}{c}\mathrm{M} \\
(\mathrm{N}=37)\end{array}$ & $\begin{array}{c}\mathrm{O} \\
(\mathrm{N}=133)\end{array}$ & $\begin{array}{c}\mathrm{K} \\
(\mathrm{N}=327)\end{array}$ & $\begin{array}{c}\mathrm{M} \\
(\mathrm{N}=115)\end{array}$ & $\begin{array}{c}\mathrm{O} \\
(\mathrm{N}=442)\end{array}$ \\
\hline \multirow{2}{*}{ I } & M & 46,8 & 45,0 & 46,3 & 46,7 & 47,6 & 46,9 & 45,7 & 44,7 & 45,4 & 46,4 & 45,9 & 46,3 \\
\hline & SD & 6,1 & 7,0 & 6,4 & 6,4 & 5,3 & 6,1 & 5,2 & 5,8 & 5,4 & 6,0 & 6,1 & 6,0 \\
\hline \multirow{2}{*}{ ES } & $\mathrm{M}$ & 54,1 & 53,0 & 53,8 & 52,6 & 50,1 & 52,0 & 52,1 & 52,1 & 52,1 & 52,8 & 51,6 & 52,5 \\
\hline & SD & 9,6 & 10,0 & 9,7 & 9,3 & 10,3 & 9,6 & 7,5 & 7,3 & 7,4 & 8,9 & 9,4 & 9,0 \\
\hline \multirow{2}{*}{ A } & $\mathrm{M}$ & 49,1 & 49,4 & 49,2 & 47,8 & 47,2 & 47,7 & 47,0 & 47,6 & 47,2 & 47,9 & 48,0 & 47,9 \\
\hline & SD & 8,3 & 9,3 & 8,6 & 8,6 & 7,7 & 8,4 & 7,2 & 7,1 & 7,1 & 8,1 & 8,0 & 8,1 \\
\hline \multirow{2}{*}{$\begin{array}{l}\text { Wynik } \\
\text { łączny }\end{array}$} & M & 181,8 & 178,3 & 180,8 & 179,2 & 176,4 & 178,5 & 176,4 & 176,0 & 176,3 & 179,0 & 176,8 & 178,4 \\
\hline & SD & 24,1 & 27,6 & 25,1 & 23,9 & 23,3 & 23,7 & 19,3 & 20,4 & 19,5 & 22,7 & 23,6 & 22,9 \\
\hline
\end{tabular}

Objaśnienia: K - kobiety; M - mężczyźni; O - ogółem; I - kompetencje warunkujące efektywność zachowań w sytuacjach intymnych; ES - kompetencje warunkujące efektywność zachowań w sytuacjach ekspozycji społecznej; A - kompetencje warunkujące efektywność zachowań w sytuacjach wymagających asertywności.

Źródło: opracowanie własne. 


\subsection{UCZESTNICTWO W PRAKTYKACH ZAWODOWYCH}

Elementem edukacji akademickiej oraz realizowanego programu kształcenia na kierunku turystyka i rekreacja są praktyki zawodowe, które studenci odbywają w przedsiębiorstwach świadczących usługi turystyczne i rekreacyjne. Celem praktyk zawodowych jest pozyskanie dodatkowych praktycznych umiejętności, rozwinięcie kluczowych cech i umiejętności przez absolwentów, zdobycie doświadczenia zawodowego oraz wzięcie odpowiedzialności za wykonywane zadania, wypracowanie postaw i standardów odpowiednich w danym zawodzie (Busby, 2003), ale także zapewnienie możliwości rozwoju, które mogą wpływać na oczekiwania i wybory zawodowe w branży turystycznej (Kim, Park, 2013). Ponadto praktyki zawodowe pomagają studentom powiązać zagadnienia teoretyczne z praktycznymi (Busby, 2003) oraz przygotować się do wejścia na rynek pracy.

W kategorii kompetencji społecznych najczęściej wskazuje się na kształtowanie umiejętności pracy w zespole i komunikowania się oraz na kwestie etyki zawodowej (np. świadomość wpływu działań na innych, przejmowanie odpowiedzialności), co stanowi element efektów kształcenia (Klimkiewicz, 2015; Maertz, Stoeberl, Marks, 2014; Narayanan, Olk, Fukami, 2010; Templeton, Updyke, Bennett, 2012; Ward, Yates, 2013).

Podjęto więc próbę ustalenia, czy praktyki zawodowe zrealizowane przez studentów turystyki i rekreacji mają związek ze zróżnicowaniem poziomu kompetencji społecznych. Długość odbytych praktyk zależy od tego, na którym roku studiował respondent oraz czy był on absolwentem liceum ogólnokształcącego czy technikum ${ }^{4}$.

Z badań wynika, że najwięcej osób (41,9\%) odbyło praktyki, które trwały jeden miesiąc, i są to studenci III roku studiów licencjackich, będący absolwentami liceum ogólnokształcącego. Pozostali respondenci odbyli nieco dłuższe praktyki - 19,0\% było na praktykach przez dwa miesiące, 10,0\% - przez trzy, 3,1\% - cztery, 2,5\% - pięć miesięcy. Najdłuższymi praktykami, trwającymi 5 miesięcy, mogą pochwalić się studenci II roku studiów magisterskich, którzy ukończyli technikum o profilu hotelarskim, gastronomicznym, obsługi ruchu turystycznego. Część respondentów (23,5\%) do czasu przeprowadzania badania nie odbyła jeszcze żadnych praktyk. Zdecydowana większość respondentów $(87,8 \%)$ otrzymała z praktyk ocenę bardzo dobra, co dziesiąty $(11,0 \%)$ - dobra, znikoma część (1,2\%) - dostateczną. Wyniki analizy korelacji z użyciem testu r-Pearsona nie wskazały statystycznie istotnych zależności pomiędzy stażem praktyk zrealizowanych przez studentów w szkole średniej (technikum) oraz na studiach a którąkolwiek ze skal kwestionariusza KKS, wykorzystywanego w celu zbadania kompetencji społecznych.

\subsection{UCZESTNICTWO W MIĘDZYNARODOWYCH WYMIANACH A KOMPETENCJE SPOŁECZNE}

Odmiennym rodzajem doświadczeń akademickich było uczestnictwo studentów w międzynarodowej wymianie w ramach programu Erasmus (i innych tego typu). Założono bowiem, iż funkcjonowanie w środowisku wielokulturowym może mieć istotny związek z różnicowaniem kompetencji społecznych studentów uczestniczących w takim programie. Erasmus, jak wskazuje wiele badań, ułatwia studentom zdobywanie wiedzy, doświadczeń międzynarodowych, kwalifikacji zawodowych, a także wspomaga wszechstronny rozwój osobisty i społeczny (Alejziak, 2018a; 2018b; Cvikl, Artic, 2013; Dhiman, 2012; Dolga, Filipescu, Popescu-Mitroi, Mazilescu, 2015; Krawczyk-Bryłka, 2014; Milne, Cowie, 2013).

Z przeprowadzonych na potrzeby niniejszego artykułu badań wynika, że więcej niż co dziesiąty student $(12,4 \%)$ uczestniczył w takiej wymianie. Tym samym $87,6 \%$ respondentów nie skorzystało z tej możliwości. Podczas analizy brano pod uwagę takie aspekty, jak: wyjazd w ogóle, czas trwania i charakter wyjazdu (edukacja, edukacja i praktyka, praktyka). Badając uczestnictwo w tego typu programach zarówno w szkole średniej, jak i na studiach, można zauważyć, że czas trwania takich wyjazdów mieścił się w granicach od 1 do 10 miesięcy. Wyjazdy o charakterze edukacyjnym realizowane na poziomie nauki akademickiej trwały zwykle jeden lub dwa semestry. Z kolei praktyki i staże miały zróżnicowaną długość, zależnie od potrzeb pracodawcy przyjmującego do pracy za granicą.

Studenci I roku najczęściej w szkole średniej decydowali się na wyjazdy trwające od jednego do trzech miesięcy. Natomiast w najdłuższych wyjazdach (510 miesięcy) uczestniczyły osoby będące na studiach magisterskich. Charakter tych podróży był dość zróżnicowany. Najwięcej spośród wyjeżdżających osób uczestniczyło w wymianie o charakterze edukacyjnym $(65,8 \%)$, co czwarty student $(23,7 \%)$ wyjechał na praktyki, a co dziesiąty (10,5\%) łączył edukację z praktyką. Z analizy tych kategorii wynika, że na studiach licencjackich i magisterskich rozkład wskaźników procentowych jest dość zbliżony (I rok studiów licencjackich - 61,8\%, 20,6\%, 17,6\%; II i III rok - 69,6\%, 26,1\%, $4,3 \%$; osoby na studiach uzupełniających magisterskich $-68,4 \%, 26,3 \%, 5,3 \%)$.

Na podstawie przeprowadzonych analiz statystycznych nie stwierdzono różnic w poziomie kompetencji społecznych pomiędzy osobami, które uczestniczyły $\mathrm{w}$ wymianie tego typu, a pozostałymi badanymi $(p>0,05)$. Ponadto nie dostrzeżono istotnych zależności między czasem trwania takich wyjazdów a wynikami kwestionariusza KKS $(p>0,05)$. Nie zaobserwowano 
także, aby charakter wyjazdu (edukacja, praktyka lub edukacja i praktyka) różnicował badanych pod względem ich kompetencji społecznych.

\section{PODSUMOWANIE I WNIOSKI}

Poziom kompetencji społecznych determinuje jakość relacji z innymi ludźmi oraz skuteczność i atrakcyjność interpersonalną. Osoby, które prezentują wysoki poziom kompetencji społecznych, mają umiejętność współdziałania, potrafią pracować w zespole, rozwiązywać konflikty, działają też bardziej efektywnie (Bandach, 2013; Smółka, 2008). Wymienione kompetencje są szczególnie przydatne w pracy w usługach turystycznych i rekreacyjnych, gdzie funkcjonowanie oparte jest na tzw. umiejętnościach miękkich (Yurur, Koc, Taskin, Boz, 2018), których rola według prognoz ma jeszcze wzrosnąć (Czarnik i in., 2019). Umiejętności miękkie są postrzegane nie tylko jako istotne w pracy w ogóle, ale przede wszystkim zwiększające szanse absolwentów na znalezienie zatrudnienia w branży turystycznej i hotelarskiej. Pracodawcy starają się pozyskać wszechstronnie wykształconych pracowników, którzy posiadają nie tylko odpowiednią wiedzę, ale są również kompetentni w zakresie umiejętności technicznych oraz interpersonalnych (Chan, 2011).

W trakcie prowadzenia badań założono, iż aktywność akademicka, realizowany program kształcenia na danej uczelni oraz wskazane tam efekty kształcenia w zakresie kompetencji społecznych stanowią ważną formę treningu społecznego dla młodzieży akademickiej studiującej na kierunku turystyka i rekreacja. Przyjęto także, iż w toku edukacji na studiach licencjackich i magisterskich w ich obrębie powinny zachodzić zmiany ilościowe i jakościowe. W tym kontekście studenci z dłuższym stażem akademickim powinni osiągać wyższe wyniki w KKS, czego badania nie potwierdziły.

Warto jednak zwrócić uwagę na fakt, że trening społeczny to tylko jeden wymiar decydujący o efektywności doskonalenia kompetencji społecznych, pozostałe to cechy temperamentalne oraz intelektualne danej jednostki. Dopiero interakcja tych trzech czynników wyznacza w koncepcji Matczak (2001) kategorię, do której aspirują programy nauczania oraz ich efektywność. Nie mając wiedzy na temat cech temperamentalnych studentów i nie znając ich poziomu inteligencji (zwłaszcza społecznej), można uznać, że oddziaływania mają wpływ jedynie na pewną część zmienności wyniku osiąganego poziomu kompetencji społecznych.

Zaskakujący może być wyższy wynik kompetencji społecznych, ale tylko w przypadku skali I (kompetencje warunkujące efektywność zachowań w sytuacjach intymnych) studentów z krótszym stażem akademickim. Należy jednak zwrócić uwagę na to, że badania mają charakter przekrojowy i w tym kontekście musimy brać pod uwagę fakt, iż studenci nie stanowią homogenicznej grupy. Warto również podkreślić, iż w praktyce akademickiej założenie, czy efekty kształcenia, szczególnie w zakresie kompetencji społecznych, zostały osiągnięte, opiera się na deklaracji i subiektywnej ocenie nauczyciela akademickiego, a nie na kryterium zewnętrznym.

W badaniach założono także, iż uczestnictwo studentów w międzynarodowym programie wymiany (edukacja i praktyki) może mieć związek z wyższym poziomem kompetencji społecznych tych osób. Co ciekawe, wyniki nie wykazały żadnej korelacji, nawet przy uwzględnieniu specyfiki wyjazdu (nauka, praca, nauka i praca) czy długości brania udziału w programie (od 1 do 10 miesięcy). Okazało się zatem, że doświadczenie uczestnictwa w programie międzynarodowej wymiany młodzieży także nie jest związane z poziomem rozwoju kompetencji społecznych.

Z badań Alejziak (2018a) wynika, że uczestnicy tego typu wyjazdów zauważają jednak wiele innych korzyści, takich jak: doskonalenie znajomości języków obcych, zdobywanie i poszerzanie wiedzy, poznanie kultury odwiedzanego kraju, zaznajomienie się z innymi metodami kształcenia, kształtowanie umiejętności radzenia sobie w trudnych sytuacjach życiowych, większa dojrzałość. Samo doświadczenie nauki lub pracy jest także predyktorem wzrostu wrażliwości kulturowej (Yurur, Koc, Taskin, Boz, 2018). Z kolei Jacob, Kühhirt, Rodrigues (2019) zwrócili uwagę na wyższość kształcenia akademickiego w zachodniej części Europy w opinii młodzieży. Z innych analiz wynika także, że studenci wyjeżdżający na wymiany zagraniczne, zwykle nie biorą w sposób świadomy pod uwagę celów związanych z rozwojem osobistym (Petzold, Moog, 2018), a wyjazd traktują niekiedy jako wspaniałą przygodę i rozrywkę (Alejziak, 2019). Należy także zauważyć, iż do badań uczestników wyjazdów nie wykorzystano wystandaryzowanego narzędzia psychologicznego, służącego do badania poziomu kompetencji społecznych, a jedynie ankietę mającą na celu poznanie opinii tych osób.

Szczególnym rodzajem treningu akademickiego są niewątpliwie praktyki zawodowe, odzwierciedlające rzeczywistość w środowisku pracy w danym zawodzie. Należałoby więc spodziewać się zróżnicowania poziomu kompetencji społecznych w zależności od długości realizacji praktyk oraz otrzymanej z nich oceny. Zdecydowana większość studentów uzyskała ocenę bardzo dobra, co słabo różnicuje ich między sobą. Biorąc pod uwagę, że kształtowanie kompetencji społecznych to proces, czas trwania praktyk od jednego do pięciu miesięcy z pewnością jest zbyt krótki, aby zauważyć jakieś efekty. Należy jednak założyć, że praktyki stanowią ważny etap w życiu młodego człowieka (chociaż bardzo krótki), mający związek z kształtowaniem omawianych tu kompetencji. 
W świetle przedstawionych danych wynik osiagnięty w przypadku badanych osób jest dość zaskakujący. Najbardziej zwraca uwagę brak różnic między trzema grupami studentów. Zakładając, że w toku edukacji akademickiej kształtowane są kompetencje społeczne, należy się spodziewać, że będą one wzrastać wraz z długością stażu akademickiego. Przyczyną otrzymania przeciętnego wyniku kompetencji społecznych w grupie badanych studentów może być panujący w szkołach wyższych powszechny pogląd, że w odniesieniu do studentów głównym - jeśli nie jedynym - zadaniem uczelni jest ich kształcenie. Ponadto Wasielewski (2014) zwraca uwagę, że pomimo częstych deklaracji o wielkim znaczeniu dydaktyki akademickiej, na uczelniach wyższych widać wyraźnie, iż wykładowcy znacznie większą wagę przywiązują do pracy naukowowo-badawczej warunkującej ich rozwój i awans zawodowy.

Natomiast Brzezińska, Kaczan, Piotrowski i Rękosiewicz (2011) zauważają jeszcze inny aspekt, z którego wynika, że w grupie współczesnej młodzieży należy uwzględnić pojawiające się zjawisko „odroczonej dorosłości", które polega na coraz późniejszym wkraczaniu w dojrzałe, dorosłe życie. W związku z tym okres studiów staje się dodatkowym czasem, który młody człowiek zyskuje na ukształtowanie swojej osobowości i tożsamości.

Należy także zwrócić uwagę na fakt, że badania miały charakter przekrojowy. $Z$ tego powodu bardzo ostrożnie należy interpretować ich wyniki wskazujące na brak różnic między grupami kolejnych roczników oraz poziom osiągnięcia zakładanych przez nauczycieli akademickich efektów kształcenia w zakresie kompetencji społecznych. Dodatkowo na uczelniach wyższych obowiązuje dwustopniowy system kształcenia oraz rekrutacji, co skutkuje tym, iż badani studenci z grupy trzeciej (studia uzupełniające magisterskie) byli potencjalnie absolwentami innych uczelni, a niekiedy nawet innych kierunków. Wynik ten potwierdza zakładane we wstępie założenia dotyczące ewaluacji poziomu tych kompetencji. Nasuwa się wniosek odnośnie do zasadności wypracowania pewnych form ewaluacji poziomu rozwoju kompetencji społecznych u studentów, przy założeniu zachowania prywatności, a jednocześnie trafności i rzetelności metodologii. Kryteria samooceny $\mathrm{w}$ tym zakresie i jedynie arbitralnej oceny wykładowców są zbyt subiektywne, by można było na tej podstawie kształtować i elastycznie modyfikować cele związane z rozwojem kompetencji społecznych.

Kolejnym polem do dyskusji jest natura zakładanych celów. Kompetencje społeczne są to cechy osobowości, a ich rozwój wymaga ukierunkowanych działań o charakterze rozwijającym lub korygującym i tylko $\mathrm{w}$ bardzo intensywnym, niekiedy nawet warsztatowym wymiarze może przynosić skutki (Muralidhar i in., 2016). Cel ten musi być również autonomiczny dla samych studentów, którzy muszą w odpowiednim czasie wykazać się nie tylko motywacja, ale i gotowością do zmiany.

\section{PRZYPISY}

1 Zamiast pojęcia efektów uczenia się stosuje się także termin „efekty kształcenia”, traktowany często jako synonim. Istotą i nadrzędnym celem nowocześnie pojmowanego procesu kształcenia jest spowodowanie, aby - w wyniku zastosowania właściwych metod dydaktycznych - student „,nauczył się", , a nie żeby „został nauczony”. W tym sensie sformułowanie „efekty uczenia się” jest bardziej adekwatne do współczesnych wymogów edukacji niż powszechnie używany i przyjęty termin „efekty kształcenia” (Chmielecka, 2010; Poczmańska, Stęchły, 2018). Sławiński (2016) wyjaśnia jednak, że w Ustawie z dnia 27 lipca 2005 r. - Prawo o szkolnictwie wyższym istnieje rozróżnienie między efektami kształcenia, które są uzyskiwane w procesie kształcenia w systemie studiów, a efektami uczenia się, osiąganymi w procesie uczenia się poza systemem studiów. Rozróżnienie to nie występuje poza szkolnictwem wyższym (Ustawa, 2005).

2 Badania oraz konsultacje psychologiczne podczas interpretacji wyników: mgr Katarzyna Supernat, asystentka na Wydziale Wychowania Fizycznego i Sportu, Instytut Nauk Społecznych, Zakład Psychologii AWF Kraków.

${ }^{3}$ Kwestionariusz Samooceny Osiągnięć Zawodowych Studenta został wykorzystany do zdiagnozowania rozwoju zawodowego studentów na różnych etapach kształcenia i obejmował takie aspekty, jak: plany zawodowe, motywy rozpoczęcia studiów na kierunku turystyka i rekreacja, znajomość języków obcych, osiagnięcia edukacyjne, zawodowe, sportowe, zainteresowania zawodowe, odbyte kursy i szkolenia zawodowe, nabyte uprawnienia potwierdzone dyplomem lub zaświadczeniem, poziom i zakres doświadczenia zawodowego, czyli staż pracy, zajmowane stanowiska pracy w sektorze usług turystycznych oraz $\mathrm{w}$ innych sektorach gospodarki itp.

${ }_{4}$ Zgodnie z Załacznikiem nr 8 do Rozporzadzenia Ministra Edukacji Narodowej z dnia 7 lutego 2012 r. w sprawie ramowych planów nauczania w szkołach publicznych (2012) praktyki zawodowe w technikum są realizowane w wymiarze określonym w podstawie programowej kształcenia w danym zawodzie; o tym, kiedy (w której klasie) uczniowie je odbywaja, decyduje dyrektor szkoły. Wymiar godzin praktyk zawodowych dla poszczególnych zawodów został określony w Rozporzadzeniu Ministra Edukacji Narodowej $z$ dnia 7 lutego 2012 r. w sprawie podstawy programowej kształcenia w zawodach (2012). Uczeń jest kierowany do odbycia praktyk zawodowych we wskazanym we wspomnianym rozporządzeniu wymiarze. W odniesieniu do praktyk zawodowych zastosowanie mają również postanowienia Rozporządzenia Ministra Edukacji Narodowej z dnia 15 grudnia 2010 r. w sprawie praktycznej nauki zawodu (2010). Zgodnie z przepisem zawartym w § 4, ust. 3 przywołanego rozporządzenia praktyki zawodowe organizuje się dla uczniów w celu zastosowania i pogłębienia zdobytej wiedzy i umiejętności zawodowych w rzeczywistych warunkach pracy. Natomiast zgodnie z przepisem zawartym w $\S 4$, ust. 6 wspomnianego rozporządzenia zakres wiadomości i umiejętności nabywanych przez uczniów na zajęciach praktycznych i w trakcie praktyk zawodowych oraz wymiar godzin tych zajęć i praktyk określa program nauczania dla danego zawodu zaakceptowany w danej szkole przez jej dyrektora (Praktyka zawodowa, 2020). Z kolei na kierunku turystyka i rekreacja w Akademii Wychowania Fizycznego w Krakowie liczba godzin odbytych praktyk przez studenta wynika z Planów studiów obowiązujących 
studentów, którzy rozpoczęli studia w latach 2013-2018 (zob. Plany studiów AWF Kraków, 2013-2018). Na studiach licencjackich, podobnie jak na magisterskich, student realizował po 160 godzin praktyk, co wynikało z ogólnoakademickiego profilu obowiązującego w czasie przeprowadzania badań (zob. Plany studiów AWF Kraków, 2013-2018). Warto wyjaśnić, iż od 2018 r. studia pierwszego stopnia na kierunku turystyka i rekreacja w AWF Kraków mają charakter praktyczny. Tak więc studenci, którzy rozpoczęli studia w tym właśnie roku, zobowiązani są zrealizować 720 godzin praktyk na szóstym semestrze edukacji, co stanowi znaczącą zmianę w kontekście kształcenia umiejętności zawodowych w porównaniu do profilu ogólnoakademickiego, w którego ramach przeprowadzone zostały badania prezentowane w niniejszym artykule.

\section{BIBLIOGRAFIA}

Alejziak, B. (2014). Kwalifikacje i kompetencje pracowników turystyki. Diagnoza turystycznego rynku pracy. Folia Turistica, 32, 117-144.

Alejziak, B. (2018a). Międzynarodowa turystyka edukacyjna a rozwój osobisty i zawodowy młodzieży studenckiej. Zeszyty Naukowe MWSE, 1 (37), 115-134. DOI: https://doi.org/10.25944/ znmwse.2018.01.115134

Alejziak, B. (2018b). Międzynarodowa turystyka edukacyjna młodzieży studenckiej a motywy wyjazdu. Kraków: Wydawnictwo Krakowskiej Akademii im. A. Frycza Modrzewskiego.

Alejziak, B. (2019). Działalność autokreacyjna młodzieży studenckiej a edukacja nieformalna podczas międzynarodowych wyjazdów edukacyjnych. Szkoła. Zawód. Praca, 17, 182-200, DOI: https://doi.org/10.34767/SZP.2019.01.13

Argyle, M. (1998). Zdolności społeczne. W: S. Moccovici (red.), Psychologia społeczna w relacji ja-inni (s. 77-104). Warszawa: Wydawnictwa Szkolne i Pedagogiczne.

Argyle, M. (1999). Psychologia stosunków międzyludzkich. Warszawa: Wydawnictwo Naukowe PWN.

Bandach, M. (2013). Trening umiejętności społecznych jako forma podnoszenia kompetencji społecznych. Economics and Management, 4, 82-97. DOI: http://dx.doi.org/10.12846/j. em.2013.04.06

Bereźnicki, F. (2011). Szkolnictwo wyższe w procesie przemian. Edukacja Humanistyczna. Pótrocznik myśli społeczno-pedagogicznej, 2 (25), 7-12.

Brzezińska, A.I., Kaczan, R., Piotrowski, K., Rękosiewicz, M. (2011). Odroczona dorosłość: fakt czy artefakt? Nauka, 4, 67-107.

Burzyński, T. (red) (2019). Badanie opinii pracodawców na temat obecnych i przyszlych kompetencji pracowników w sektorze turystyki. Kraków: Rada ds. Kompetencji Sektora Turystyka, Instytut Turystyki w Krakowie Sp. z o.o.

Busby, G. (2003). Tourism degree internships: A longitudinal study. Journal of Vocational Education and Training, 55 (3), 319-334. DOI: https://doi.org/10.1080/13636820300200232

Chan, J.K.L. (2011). Enhancing the employability of and level of soft skills within tourism and hospitality graduates in Malaysia: The issues and challenges. Journal of Tourism, 12 (1), 1-16.

Chłoń-Domińczak, A., Sławiński, S., Kraśniewski, A. (2015). Raport referencyjny. Odniesienie Polskiej Ramy Kwalifikacji na rzecz uczenia się przez całe życie do Europejskiej Ramy Kwalifikacji. Warszawa: Instytut Badań Edukacyjnych. Pobrane z: http:// kwalifikacje.edu.pl/wp-content/uploads/publikacje/PDF/ Raport-referencyjny_aktualizacja.pdf (15.03.2020).

Chłoń-Domińczak, A., Sławiński, S., Kraśniewski, A., Chmielecka, E. (2017). Polska Rama Kwalifikacji. Warszawa: Instytut
Badań Edukacyjnych. Pobrane z: http://www.kwalifikacje. gov.pl/images/Publikacje/Polska-rama-kwalifikacji.pdf (20.03.2020).

Chmielecka, E. (2010). Autonomia programowa uczelni. Ramy kwalifikacji dla szkolnictwa wyższego. Warszawa: Wydawca Ministerstwo Nauki i Szkolnictwa Wyższego, Projekt Ministerstwa Nauki i Szkolnictwa Wyższego „Krajowe Ramy Kwalifikacji w szkolnictwie wyższym jako narzędzie poprawy jakości kształcenia" Priorytet IV PO KL, Działanie 4.1. Poddziałanie 4.1.3.

Cohen J. (1988). Statistical power analysis for the behavioral sciences second edition. Mahwah-Nowy Jork: Lawrence Erlbaum.

Cohen, J., Cohen, P., West, S.G., Aiken, L.S. (2003). Applied multiple regression/correlation analysis for the behavioral sciences. Wyd. 3. Mahwah-Nowy Jork: Lawrence Erlbaum.

Cvikl, H., Artic, N. (2013). Can mentors of Erasmus students mobility influence the development of future tourism? Tourims and Hospitality Management, 19 (1), 83-95.

Czarnik, S., Górniak, J., Jelonek, M., Kasparek, K., Kocór, M., Lisek, K., Prokopowicz, P., Strzebońska, A., Szczucka, A., Worek, B. (2019). Aktywność zawodowa i edukacyjna dorostych Polaków wobec wyzwań wspótczesnej gospodarki. Raport podsumowujacy VI edycję badania BKL w latach 2017-2018. Warszawa: Polska Agencja Rozwoju Przedsiębiorczości.

Dhiman, M.Ch. (2012). Employers perception and tourism management employability skills. Anatolia - An International Journal of Tourism and Hospitality Research, 23 (3), 359-372. DOI: https:// doi.org/10.1080/13032917.2012.711249

Dolga, L., Filipescu, H., Popescu-Mitroi, M.M., Mazilescu, C.A. (2015). Erasmus mobility impact on professional training and personal development of students beneficiaries. Procedia. Social and Behavioral Sciences, 191, 1006-1013. DOI: https://doi. org/10.1016/j.sbspro.2015.04.235

Europejskie Ramy Kwalifikacji dla uczenia się przez całe życie (ERK) (2009). Luksemburg: Urząd Oficjalnych Publikacji Wspólnot Europejskich. DOI: https://doi.org/10.2766/25471

Goleman, D. (1997). Inteligencja emocjonalna. Poznań: Media Rodzina.

Greenspan, S. (1981). Defining childhood social competence: A proposed working model. W: B.K. Keogh (red.), Advances in special education. T. 3 (s. 1-39). Greenwich: JAI Press.

Jacob, M., Kühhirt, M., Rodrigues, M. (2019). Labour market returns to graduates. International European Sociological Review, 35 (4), 491-505. DOI: https://doi.org/10.1093/esr/jcz022

Jakubowska, U. (1996). Wokół pojęcia "kompetencja społeczna” - ujęcie komunikacyjne. Przeglad Psychologiczny, 39, 29-40.

Kim, H.B., Park, E.J. (2013). The role of social experience in undergraduates' career perceptions through internships. Journal of Hospitality, Leisure, Sport \& Tourism Education, 12 (1), 70-78. DOI: https://doi.org/10.1016/j.jhlste.2012.11.00

Klimkiewicz, K. (2015). Rola praktyk studenckich w doskonaleniu praktycznego aspektu kształcenia studentów uczelni wyższych. Studia Ekonomiczne. Zeszyty Naukowe Uniwersytetu Ekonomicznego w Katowicach, 225, 93-101.

Kraśniewski, A. (2009). Proces Boloński. Warszawa: Fundacja Rozwoju Systemu Edukacji.

Krawczyk-Bryłka B. (2014). Kompetencje międzykulturowe a udział w programie Erasmus. Przedsiębiorstwo we Wspótczesnej Gospodarce - Teoria i Praktyka, 1, 17-27.

Maertz, C.P., Stoeberl, P.A., Marks, J. (2014). Building successful internships: Lessons from the research for interns, schools, and employers. Career Development International, 19, 123-142. DOI: https://doi.org/10.1108/CDI-03-2013-0025

Maher, A. (2004). Learning outcomes in higher education: Implications for curriculum design and student learning. Journal of Hospitality, Leisure, Sport and Tourism Education, 3 (2), 46-54. DOI: https://doi.org/10.3794/johlste.32.78 
Matczak, A. (2001). Kwestionariusz Kompetencji Społecznych (KKS) Podręcznik. Warszawa: Pracownia Testów Psychologicznych Polskiego Towarzystwa Psychologicznego.

Miles, J., Shevlin, M. (2001). Applying regression and correlation: A guide for students and researchers. London: SAGE Publications Ltd.

Milne, A., Cowie, J. (2013). Promoting culturally competence care: The Erasmus exchange programme. Nursing Standard, 27 (30), 42-46. DOI: https://doi.org/10.7748/ns2013.03.27.30.42.e7215

Muralidhar, S., Nguyen, L.S., Frauendorfer, D., Odobez, J.M., Schmid Mast, M., Gatica-Perez, D. (2016). Training on the job: Behavioral analysis of job interviews in hospitality. W: Y.I. Nakano, E. André, T. Nishida (red.), Proceedings of the 18th AMC international conference on multimodal interaction (s. 84-91). Nowy Jork: Association for Computing Machinery. DOI: https://doi. org/10.1145/2993148.2993191

Narayanan, V.K., Olk, P.M., Fukami, C.V. (2010). Determinants of internship effectiveness: An exploratory model. Academy of Management Learning \& Education, 9 (1), 61-80. DOI: https:// doi.org/10.5465/AMLE.2010.48661191

Nowak-Dziemianowicz, M. (2012). Kompetencje społeczne jako jeden $z$ efektów kształcenia w Krajowych Ramach Kwalifikacji w kontekście pytań o cele i funkcje edukacji. Warszawa: Instytut Badań Edukacyjnych.

Nowakowska, H., Pietkiewicz, I. (2016). Narzędzia procesu bolońskiego w opiniach studentów pomorskich uczelni. Colloquium Wydziału Nauk Humanistycznych i Społecznych Kwartalnik, 1 (21), 55-74.

Opis kierunkowych efektów kształcenia dla studiów I stopnia - profil ogólnoakademicki kierunek turystyka i rekreacja 2013/2014, zatwierdzone uchwała Senatu W2013R, Wydział Turystyki i Rekreacji Akademii Wychowania Fizycznego w Krakowie (2020). Pobrane z: http:// wtir.awf.krakow.pl/pdf/studia/tir/efekty_ksztalcenia/kierunkowe_efekty_ksztalcenia_I_stopnia_2013_2014.pdf (30.01.2020).

Opis kierunkowych efektów ksztatcenia dla studiów II stopnia - profil ogólnoakademicki kierunek turystyka i rekreacja 2013/2014, Wydział Turystyki i Rekreacji Akademii Wychowania Fizycznego w Kraków (2020). Pobrane z: http://wtir.awf.krakow.pl/pdf/studia/tir/ efekty_ksztalcenia/kierunkowe_efekty_ksztalcenia_ II_stopnia_2013_2014.pdf (30.01.2020).

Pacana, A., Woźny, A., Sobczyńska, A. (2016). Koncepcja oceny jakości programów kształcenia. Zeszyty Naukowe Politechniki Czesstochowskiej Zarzadzanie, 22, 264-273. DOI: https://doi. org/10.17512/znpcz.2016.2.23

Petzold, K., Moog, P. (2018). What shapes the intention to study abroad? An experimental approach. Higher Education, 75 (1), 35-54. DOI: https://doi.org/10.1007/s10734-017-0119-z

Piróg, D. (2016). Opóźnienia w przechodzeniu absolwentów szkół wyższych na rynek pracy: przyczyny, typologia, następstwa. Studia Ekonomiczne, 292, 144-157.

Plany studiów AWF Kraków (2013-2018). Pobrane z: https://wtir. awf.krakow.pl/studia/plany-studiow (30.01.2020).

Poczmańska, A., Stęchły, W. (2018), Efekty uczenia się i ich weryfikacja w projektach mobilności edukacyjnej. Katalog przykładów. Warszawa: Fundacja Rozwoju Systemu Edukacji.

Praktyka zawodowa (2020). Pobrane z: http://oswiataiprawo.pl/ porady/praktyka-zawodowa/ (23.05.2020).

Rocki, M. (2018). Jakość kształcenia a ekonomiczne losy absolwentów: Analiza przypadków. Nauka i Szkolnictwo Wyższe, 1 (51), 219-239. DOI: https://doi.org/10.14746/nisw.2018.1.11
Rozporzadzenie Ministra Edukacji Narodowej z dnia 15 grudnia 2010 r. w sprawie praktycznej nauki zawodu. Dz.U. 2010, nr 244, poz. 1626. Rozporzadzenie Ministra Edukacji Narodowej z dnia 7 lutego 2012 r. $w$ sprawie podstawy programowej kształcenia w zawodach. Dz.U. 2012, poz. 184

Różycki, P. (1998). Analiza czynników determinujących efekty kształcenia studentów AWF na kierunku turystyka. Folia Turistica, 8, 39-47.

Rydzewska-Włodarczyk, M. (2017). Polska Rama Kwalifikacji jako element zintegrowanego systemu kwalifikacji w Polsce. Folia Pomeranae Universitatis Technologiae. Stetinensis. Oeconomica, 335 (87/2), 245-260. DOI: https://doi.org/10.21005/ oe.2017.87.2.23

Sławiński, S. (2016). Słownik Zintegrowanego Systemu Kwalifikacji. Warszawa: Instytut Badań Edukacyjnych.

Sławiński, S. (red.) (2017). Polska Rama Kwalifikacji. Poradnik użytkownika. Warszawa: IBE. Pobrane z: http://www.kwalifikacje.gov.pl/images/Publikacje/ Polska-Rama-KwalifikacjiPoradnik-uyytkownika-2017.pdf (30.01.2020).

Smółka, P. (2008). Kompetencje społeczne. Metody pomiaru i doskonalenia umiejętności interpersonalnych. Kraków: Wolters Kluwer.

Spitzberg, B.H., Cupach, W.R. (2002). Interpersonal skills. W: M.L. Knapp, J.A. Daly (red.), Handbook of interpersonal communication (s. 564-611). Thousand Oaks: Sage.

Templeton, W., Updyke, K., Bennett, R.B. (2012). Internships and the assessment of student learning. Business Education $\mathcal{E}$ Accreditation, 4, 27-38.

Ustawa z dnia 27 lipca 2005 r. - Prawo o szkolnictwie wyższym. Dz.U. 2005, nr 164, poz. 1365, z późn. zm.

Ward, C., Yates, D. (2013). Extracurricular activities: The impact on business students' personal growth and employability. Business Education Innovation Journal, 5, 1-7.

Wasielewski, M. (2014). Kształcenie i wychowanie w szkole wyższej - pomiędzy tradycją a współczesnością. W: A. Łacina-Łanowski, J. Stanek (red.), Edukacja - wychowanie - oświata w perspektywie temporalnej (między przeszłością a wspótczesnościa) (s. 9-36). Łódź: Wydawnictwo Akademii Humanistyczno-Ekonomicznej.

Wierzejska, J. (2016). Kompetencje społeczne studentów kierunków technicznych i społecznych. Studia Edukacyjne, 39, 155-168. DOI: https://doi.org/10.14746/se.2016.38.10

Yurur, S., Koc, E., Taskin, C., Boz, H. (2018). Factors influencing intercultural sensitivity of hospitality employees. International Journal of Hospitality \& Tourism Administration, 1-19. DOI: https://doi.org/10.1080/15256480.2018.1547236

Zalecenie Parlamentu Europejskiego i Rady z dnia 23 kwietnia 2008 r. $w$ sprawie ustanowienia europejskich ram kwalifikacji dla uczenia się przez całe życie (Tekst mający znaczenie dla EOG) (2008/C 111/01), Dziennik Urzędowy Unii Europejskiej, 6.05.2008, C 111/1. Pobrane z: https://ec.europa.eu/ploteus/sites/eac-eqf/files/journal_pl.pdf (5.03.2020).

Załacznik nr 8 do Rozporzadzenia Ministra Edukacji Narodowej z dnia 7 lutego $2012 r$. w sprawie ramowych planów nauczania w szkołach publicznych. Dz.U. 2012, poz. 204.

Artykuł wpłyną: 20 lipca $2020 \mathrm{r}$ Zaakceptowano do druku: 23 października $2020 \mathrm{r}$. 